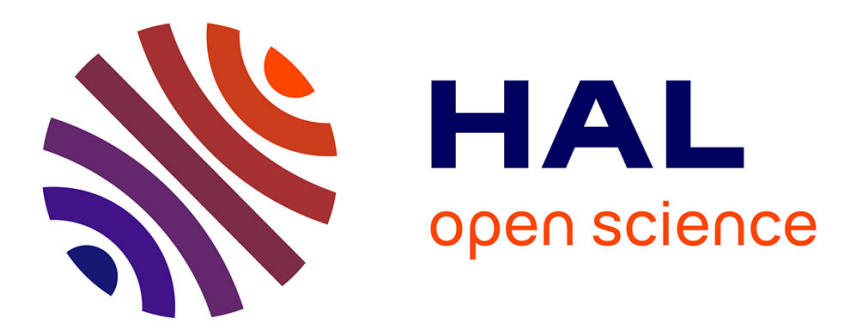

\title{
Analogues of antifungal tjipanazoles from rebeccamycin
}

Aline Voldoire, Pascale Moreau, Martine Sancelme, Maria Matulova, Stéphane Leonce, Alain Pierré, John Hickman, Bruno Pfeiffer, Pierre Renard, Nathalie Dias, et al.

\section{- To cite this version:}

Aline Voldoire, Pascale Moreau, Martine Sancelme, Maria Matulova, Stéphane Leonce, et al.. Analogues of antifungal tjipanazoles from rebeccamycin. Bioorganic and Medicinal Chemistry, 2004, 12, pp.1955-1962. 10.1016/j.bmc.2004.01.024 . hal-00136266

\section{HAL Id: hal-00136266 https://hal.science/hal-00136266}

Submitted on 13 Mar 2007

HAL is a multi-disciplinary open access archive for the deposit and dissemination of scientific research documents, whether they are published or not. The documents may come from teaching and research institutions in France or abroad, or from public or private research centers.
L'archive ouverte pluridisciplinaire HAL, est destinée au dépôt et à la diffusion de documents scientifiques de niveau recherche, publiés ou non, émanant des établissements d'enseignement et de recherche français ou étrangers, des laboratoires publics ou privés. 


\title{
Analogues of antifungal tjipanazoles from rebeccamycin
}

\author{
Aline Voldoire, ${ }^{\text {a }}$ Pascale Moreau, ${ }^{\mathrm{a}}$ Martine Sancelme, ${ }^{\mathrm{a}}$ Maria Matulova, ${ }^{\mathrm{a}}$ \\ Stéphane Léonce, ${ }^{\mathrm{b}}$ Alain Pierré, ${ }^{\mathrm{b}}$ John Hickman, ${ }^{\mathrm{b}}$ Bruno Pfeiffer, ${ }^{\mathrm{c}}$ Pierre Renard, ${ }^{\mathrm{c}}$ \\ Nathalie Dias, ${ }^{\mathrm{d}}$ Christian Bailly ${ }^{\mathrm{d}}$ and Michelle Prudhomme ${ }^{\mathrm{a}, *}$ \\ ${ }^{a}$ Université Blaise Pascal, Synthèse et Etude de Systèmes à Intérêt Biologique, UMR 6504, 63177 Aubière, France \\ bInstitut de Recherches SERVIER, Division Recherche et Cancérologie, 125 Chemin de Ronde, 78290 Croissy, France \\ ${ }^{\mathrm{c}}$ Les Laboratoires Servier, 1 Rue Carle Hébert, 92415 Courbevoie, France \\ ${ }^{\mathrm{d}}$ INSERM U-524, IRCL, 59045 Lille, France
}

\begin{abstract}
Analogues of antifungal tjipanazoles were obtained by semi-synthesis from rebeccamycin, an antitumor antibiotic isolated from cultures of Saccharothrix aerocolonigenes. The antiproliferative activities of the new compounds were evaluated in vitro against nine tumor cell lines. The effect on the cell cycle of murine leukemia L1210 cells was examined and the antimicrobial activities against two Gram positive bacteria, a Gram negative bacterium and a yeast were determined. The inhibitory properties toward four kinases and toward topoisomerase I were evaluated. The most cytotoxic compound in the series was a dinitro derivative characterized as a potent topoisomerase I inhibitor.
\end{abstract}

\section{Introduction}

Tjipanazoles A1 and A2 are antifungal agents isolated from the blue-green alga Tolypothrix tjipanasensis. Unlike protein kinase $\mathrm{C}$ inhibitors such as staurosporine and K-252a, and topoisomerase I inhibitors such as rebeccamycin, they lack the upper imide or amide heterocycle (Fig. 1). ${ }^{1-4}$ Tjipanazoles A1 and A2 were found to be inactive toward protein kinase $\mathrm{C}$, showed a weak cytotoxicity against leukemia and solid tumor cell lines but exhibited a marked fungicidal activity against rice blast and leaf rust wheat infections.

Several synthetic studies have been directed toward tjipanazoles ${ }^{5-8}$ and tjipanazoles analogues with the sugar moiety linked to both indole nitrogens, as intermediates for the synthesis of staurosporine and related compounds. $7,9-13$

In the course of structure-activity relationship studies on rebeccamycin analogues, we modified previously the functionalities in the upper heterocycle ${ }^{14,15}$ as well as on

Keywords: Rebeccamycin; Indolocarbazoles; Tjipanazoles; Antimicrobial activities; Antiproliferative activities.

* Corresponding author. Tel.: + 33-4-73-40-71-24; fax: + 33-4-73-4077-17; e-mail: mprud@chimie.univ-bpclermont.fr the sugar moiety. ${ }^{16,17}$ From the biological results, it could be deduced that the two chlorine atoms on the indolocarbazole chromophore are detrimental to the inhibition of topoisomerase I because of their bulkiness which prevents the drug from intercalating into DNA. The sugar residue is absolutely required to ensure tight interaction with DNA and topoisomerase I inhibition. ${ }^{18}$ Rebeccamycin analogues in which the sugar moiety is linked to the indolocarbazole via a $\beta$ - $N$-glycosidic bond are potent topoisomerase I inhibitors whereas compounds bearing an $\alpha$-N-glycosidic bond are inactive toward this enzyme. The introduction of a methyl group or substituents bearing a labile hydrogen $\left(\mathrm{OH}, \mathrm{NH}_{2}\right.$, $\mathrm{NHCHO}$ ) on the imide nitrogen or the replacement of the imide function by an anhydride, are compatible with topoisomerase I inhibitory activity. ${ }^{16-18}$ Generally, the rebeccamycin analogues inhibit the growth of Gram positive Streptomyces species but are inactive toward the Gram negative bacterium Escherichia coli and the yeast Candida albicans.

In this paper, we report the semi-synthesis of tjipanazoles analogues from rebeccamycin. The in vitro antiproliferative activities were tested against nine tumor cell lines: one murine leukemia (L1210), one human leukemia (K-562) and seven human solid tumors: one ovarian carcinoma (IGROV1), one neuroblastoma 

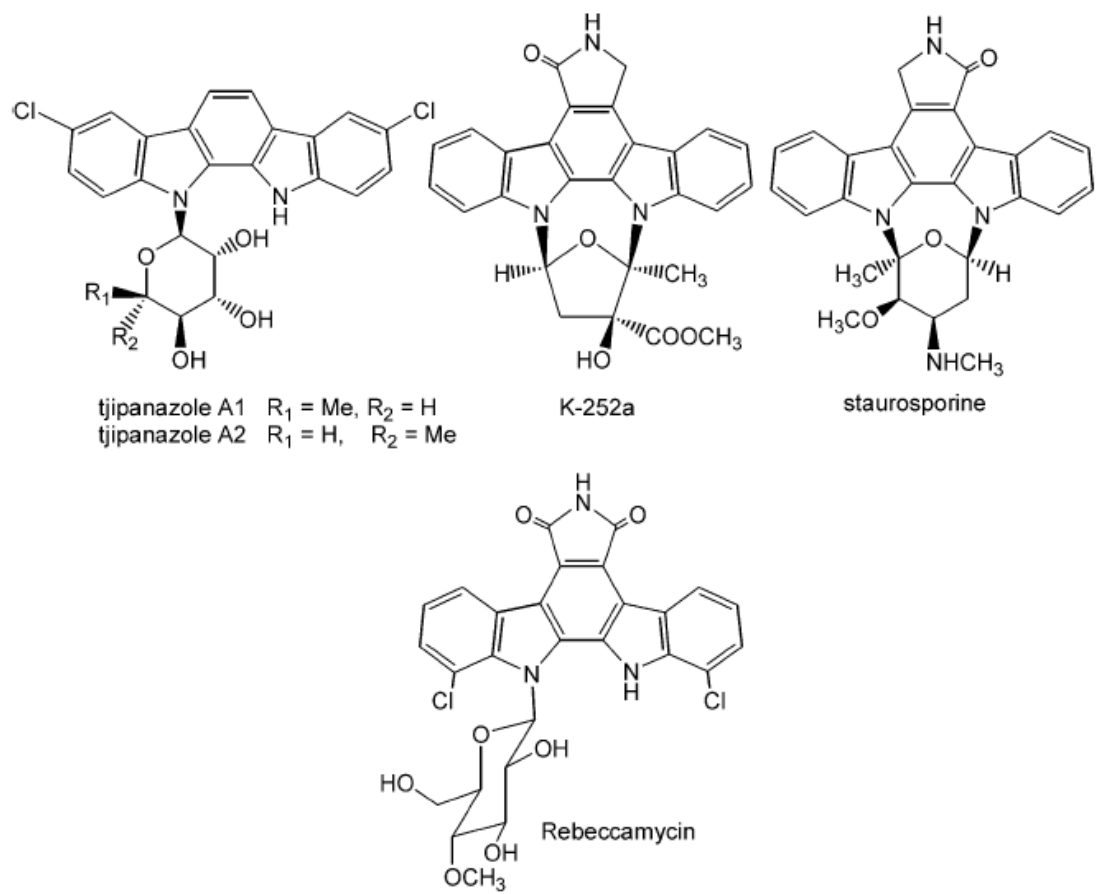

Figure 1.

(SK-N-MC), one colon carcinoma (HT29), one nonsmall cell lung carcinoma (A549), one small-cell lung carcinoma (H69) and two epidermoïd carcinomas (A431 and KB-3-1). The effect on the L1210 cell cycle was examined. The inhibitory properties toward human topoisomerase I were evaluated and the antimicrobial activities against two Gram positive bacteria Bacillus cereus and Streptomyces chartreusis, a Gram negative bacterium Escherichia coli and a yeast Candida albicans were determined.

\section{Results and discussion}

\subsection{Chemistry}

Dechlorination of rebeccamycin in a basic medium led to the dechlorinated anhydride $2,{ }^{19}$ which was further reduced using zinc-amalgam to give a mixture of lactones 3 and indolocarbazoles $\mathbf{4}$ as two regioisomers in $25 \%$ and $38 \%$ yields respectively (Fig. 2). The regioisomeric ratios calculated from ${ }^{1} \mathrm{H}$ NMR spectra were $4 / 1$ for the lactones 3 and 1.25/1 for the methylated indolocarbazoles 4. Surprisingly, further reduction of the lactones 3 to indolocarbazoles 4 using zinc-amalgam did not work. With the aim of improving the aqueous solubility of tjipanazole analogues $\mathbf{4}$, formyl and nitro substituents were introduced on the aromatic moieties. Protection of the hydroxyl groups of indolocarbazoles 4 was performed using acetic anhydride in pyridine before electrophilic substitutions. For the introduction of a formyl group, the triacetylated intermediate was treated with $\alpha$ - $\alpha$-dichloromethyl methyl ether in the presence of $\mathrm{TiCl}_{4}$ as the Lewis acid according to a method used for formylation of staurosporine and indole derivatives. ${ }^{20-22}$ Deprotection of the hydroxyl groups using 30\% aqueous ammonia in methanol allowed the isolation of the isomer $\mathbf{5}$ as the major product. The positions of both formyl and methyl groups were assigned from ${ }^{1} \mathrm{H}-{ }^{1} \mathrm{H}$ NMR COSY correlations and selective irradiations (Fig. 3). A NOE effect observed between $\mathrm{H}_{1}$, and proton $\mathrm{A}$ indicated a rotation of the carbohydrate moiety as shown in Fig. 3. This rotation in the absence of chlorine atoms at $\mathrm{A}$ and $\mathrm{A}^{\prime}$ positions has already been suggested for dechlorinated rebeccamycin, this orientation of the sugar part is very likely due to a hydrogen bond between the hydroxyl oxygen at $6^{\prime}$ position and the indole $\mathrm{NH} .^{23,24}$

Nitration of the triacetylated intermediate led mainly to the dinitro compound $\mathbf{6}$. The positions of the nitro substituents and the methyl group were assigned from ${ }^{1} \mathrm{H}-{ }^{1} \mathrm{H}$ NMR COSY correlations and selective irradiations (Fig. 4).

An analogue without the methyl group on the indolocarbazole framework was synthesized from 1,2-bis(3indolyl)ethane according to the method described by Gilbert et al. ${ }^{24}$ (Fig. 5) to get an insight into the role of the methyl group on the biological activity.

\subsection{In Vitro antiproliferative activities}

The in vitro antiproliferative activities were tested against nine tumor cell lines: one murine leukemia (L1210), one human leukemia (K-562) and seven cell lines derived from human solid tumors: one ovarian carcinoma (IGROV1), one neuroblastoma (SK-N-MC), one colon carcinoma (HT29), one non-small cell lung carcinoma (A549), one small-cell lung carcinoma (H69) and two epidermoïd carcinomas (A431 and KB-3-1). The results are reported in Table 1 . They are expressed 

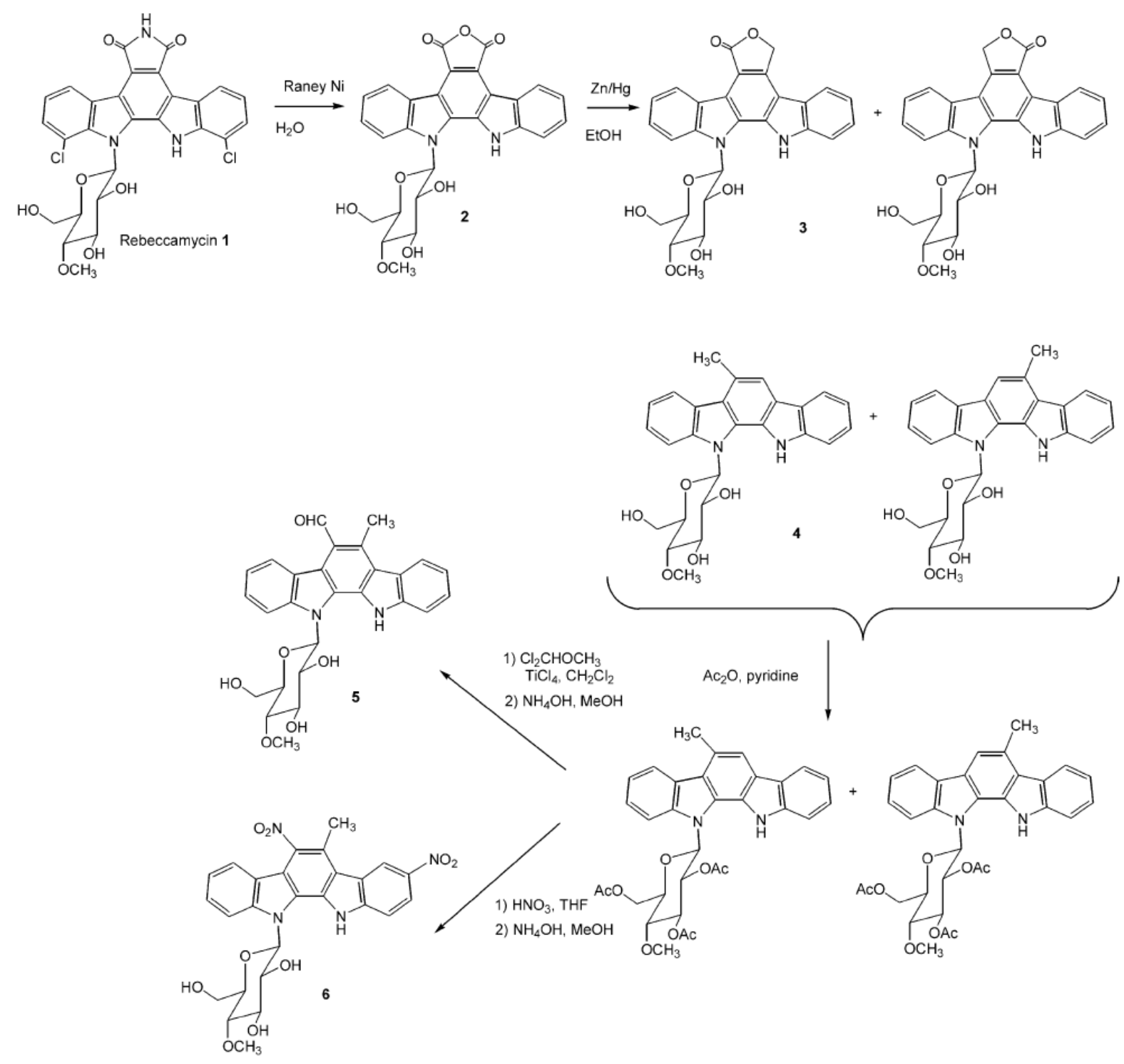

Figure 2.

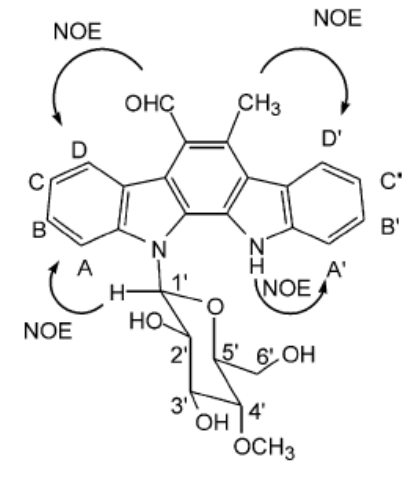

Figure 3.

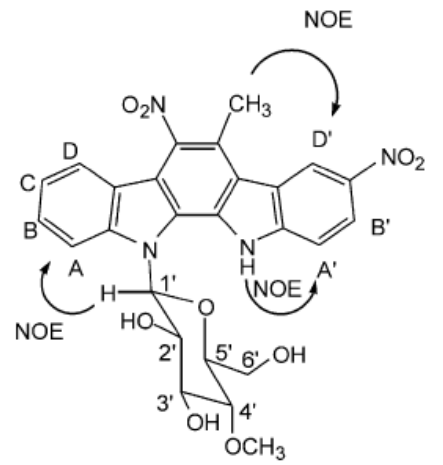

Figure 4. 


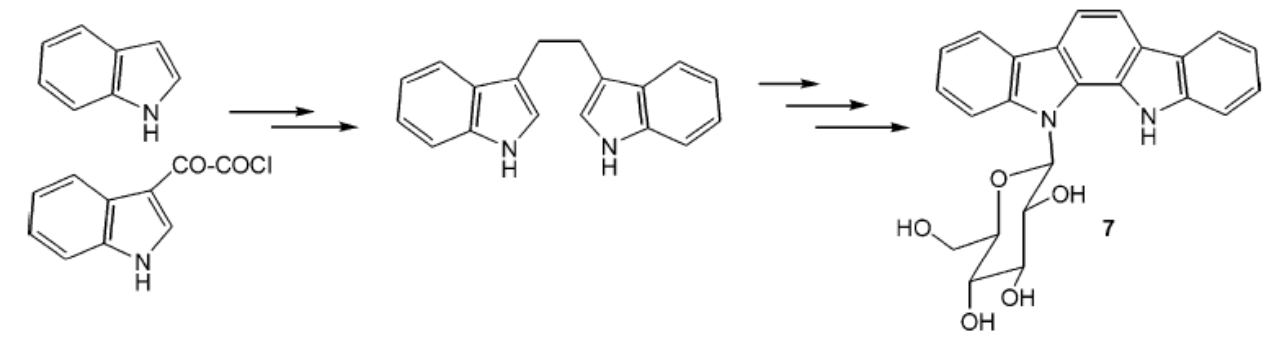

Figure 5.

as $\mathrm{IC}_{50}$ values which refer to the concentration required to reduce by $50 \%$ the optical density of treated cells with respect to untreated controls. Compared with rebeccamycin 1 , the mixture of regioisomers 4 , without the upper heterocycle, as well as compound 7, obtained by total synthesis, have lost cytotoxicity toward all the tumor cell lines tested. Compound $\mathbf{5}$, bearing a formyl group, is more efficient than compounds 4 and 7 . Compound 6 which bears two nitro substituents, exhibit the same profile of cytotoxicity than rebeccamycin with a similar efficiency against the various cell lines tested. Comparison of the antiproliferative activities of compound 6 with those of compounds 4 and 7 showed that the enhanced solubility provided by the introduction of the two nitro substituents may be responsible for the improvement of the cytotoxicity. Comparison of the cytotoxicities of compound $\mathbf{6}$ and rebeccamycin $\mathbf{1}$ seems at first sight to indicate that the imide heterocycle is not absolutely required.

\subsection{Effect on L1210 cell cycle}

In parallel, the effect on the cycle of L1210 cells of compounds which exhibit strong antiproliferative activities was investigated (Table 2). Dinitro compound 6 induced a strong accumulation of the cells in the $\mathrm{G} 2+\mathrm{M}$ phases at $0.25 \mu \mathrm{M}$ whereas rebeccamycin had a similar effect at about ten times higher concentration.

\subsection{Topoisomerase I inhibition}

Based on the structural analogy with staurosporine and rebeccamycin, the compounds were tested as potential inhibitors of protein kinase $\mathrm{C}$ and topoisomerase $\mathrm{I}$. The inhibitory potencies of compounds $4,5,6$ and 7 toward various kinases (CDK1, CDK5/p25, PKCz ERK1) and toward the phosphatase $\mathrm{Cdc} 25 \mathrm{~A}$ were evaluated but no inhibitory effect was observed. In contrast, the topoisomerase I assay gave interesting results. Compound 6, and to a minor extent compound $\mathbf{5}$, were found to stabilize topoisomerase I-DNA covalent complexes (Fig. 6). The dinitro derivative 6 strongly promotes DNA cleavage by topoisomerase I to produce a large amount of nicked DNA, as observed with the reference inhibitor camptothecin. A similar effect can be noted with rebeccamycin (1), dechlorinated rebeccamycin and a weak effect is visualized with $\mathbf{5}$ at a high concentration. In contrast, no effect was observed with compound 4 .

The effect of compounds $\mathbf{4 , 5}, \mathbf{6}$ on human topoisomerase I was investigated further using a DNA sequencing assay to identify the site of DNA cleavage in a ${ }^{32} \mathrm{P}$ labeled 117-bp DNA restriction fragment (Fig. 7). The DNA substrate was incubated with each drug at 5-50 $\mu \mathrm{M}$ prior to initiating DNA cleavage by topoisomerase I. Here again, a clear poisoning of topoisomerase I was detected with $\mathbf{5}$ and $\mathbf{6}$, but not $\mathbf{4}$. The cleavage patterns observed with the tjipanazole derivatives were comparable to those seen in the presence of camptothecin but the DNA cleavage intensity is much weaker. Surprisingly, the profiles are strictly identical to those observed with rebeccamycin and its dechloro derivative. The tjipanazoles and rebeccamycin stimulate DNA cleavage by topoisomerase I at sites TG26, TG48, CG73, and to a weaker extent at sites CG41, CG51, CG54, and TG81. Therefore, from these data we can rationalize the

Table 1. Antiproliferative activities in vitro against nine tumor cell lines: one murine leukemia (L1210), one human leukemia (K-562) and seven cell lines derived from human solid tumors: one ovarian carcinoma (IGROV1), one neuroblastoma (SK-N-MC), one colon carcinoma (HT29), one non-small cell lung carcinoma (A549), one small-cell lung carcinoma (H69) and two epidermoïd carcinomas (A431 and KB-3-1) (IC 50 $\mu$ M)

\begin{tabular}{|c|c|c|c|c|c|c|c|c|c|}
\hline Compd & $\mathrm{L} 1210$ & IgROV & SK-N-MC & HT29 & A549 & A431 & NCI-H69 & K-562 & KB-3-1 \\
\hline 1 & 0.14 & 0.25 & $<0.1$ & 0.30 & 0.30 & 0.25 & $<0.1$ & 0.20 & 0.30 \\
\hline 4 & 17.9 & $>10$ & $>10$ & $>10$ & $>10$ & $>10$ & $>10$ & $>10$ & $>10$ \\
\hline 5 & 2 & 5.5 & 6.5 & 5.5 & 5.5 & 5.2 & 1 & 3 & 5.5 \\
\hline 6 & 0.106 & 0.4 & $<0.1$ & 0.5 & 0.6 & 0.6 & $<0.1$ & $<0.1$ & 0.2 \\
\hline 7 & 18.9 & 30.8 & 19.9 & 27.1 & 30.9 & 25.5 & 26.3 & 22.2 & 18 \\
\hline
\end{tabular}

Table 2. Effect on the cycle of L1210 cells : percentage of cells recovered in the $\mathrm{G} 2+\mathrm{M}$ or $\mathrm{G} 1$ phases with a concentration of drug expressed in $\mu \mathrm{M}$

\begin{tabular}{lcccc}
\hline Compd & 1 & 4 & 5 \\
\hline Effect on the L1210 Cell Cycle & G2M $69 \%$ at $2 \mu \mathrm{M}$ & G1 $65 \%$ at $25 \mu \mathrm{M}$ & G2M $75 \%$ at $10 \mu \mathrm{M}$ & G2M $77 \%$ at $0.25 \mu \mathrm{M}$ \\
\hline
\end{tabular}

a $24 \%$ of untreated control cells were recovered in the $\mathrm{G} 2+\mathrm{M}$ phases of the cell cycle, $44 \%$ in the G1 phase. 


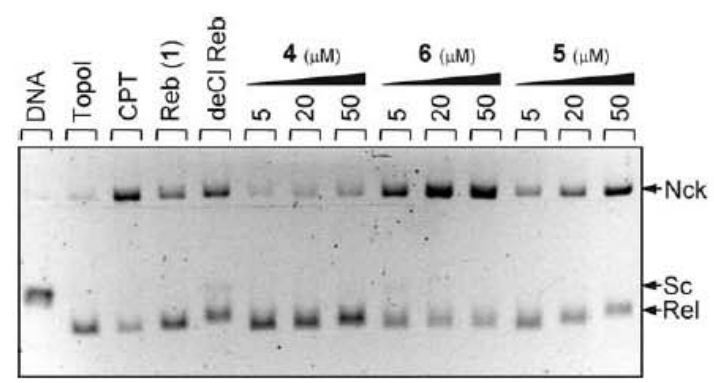

Figure 6. Drug-induced stabilization of topoisomerase I-DNA complexes. Effect of increasing concentrations of compounds 4,5 and 6 on the relaxation of plasmid DNA by human topoisomerase I. Native supercoiled pLAZ3 DNA $(0.4 \mu \mathrm{g})$ (lane DNA) was incubated with 4 units topoisomerase $\mathrm{I}$ in the absence (lane TopoI) or presence of drug at the indicated concentration $(\mu \mathrm{M})$. Camptothecin (CPT), rebeccamycin (Reb, 1) and dechlorinated rebeccamycin (deCl Reb) were used at $20 \mu \mathrm{M}$. Reactions were stopped with sodium dodecylsulfate and treatment with proteinase $\mathrm{K}$. DNA samples were separated by electrophoresis on $1 \%$ agarose gels containing ethidium $(1 \mu \mathrm{g} / \mathrm{mL})$ and then photographed under UV light. Nck, nicked; Rel, relaxed; Sc, supercoiled DNA.

Table 3. Antimicrobial activities against two Gram-positive bacteria, B. cereus and S. chartreusis, a Gram-negative bacterium E. coli, and a yeast $C$. albicans

\begin{tabular}{lcccc}
\hline Compd & $\begin{array}{c}\text { B. cereus } \\
\text { ATCC 14579 }\end{array}$ & $\begin{array}{c}\text { S. chartreusis } \\
\text { NRRL 11407 }\end{array}$ & $\begin{array}{c}\text { E. coli } \\
\text { ATCC 11303 }\end{array}$ & $\begin{array}{c}\text { C. albicans } \\
\text { IP 444 }\end{array}$ \\
\hline $\mathbf{1}$ & ++ & ++ & - & - \\
$\mathbf{2}$ & - & \pm & - & - \\
$\mathbf{4}$ & +++ & ++++ & ++ & - \\
$\mathbf{5}$ & ++++ & $\begin{array}{c}\mathrm{sp} 25 \mathrm{~mm} \\
++++\end{array}$ & - & - \\
$\mathbf{6}$ & & $\mathrm{sp} \mathrm{22 \textrm {mm }}$ & - & - \\
7 & - & ++++ & - & - \\
& +++ & +++ & & \\
\hline
\end{tabular}

The size of zones of growth inhibition was $13-16 \mathrm{~mm}(++++)$, 10-12 $\mathrm{mm}(+++), 8-9 \mathrm{~mm}(++), 7-8 \mathrm{~mm}(+), 6-7 \mathrm{~mm}( \pm)$. sp: inhibition of sporulation.

cytometry results which indicated an arrest of the cell cycle in the $\mathrm{G} 2 / \mathrm{M}$ phase with $\mathbf{6}$ and $\mathbf{5}$, that is, with the two topoisomerase I inhibitors, but not with 4 . The high cytotoxic potential of compound 6 may also be associated with its capacity to inhibit topoisomerase I. This observation is particularly interesting because this compound lacks the imide heterocycle (E-ring of rebeccamycin) which was initially thought to be essential for topoisomerase I inhibition.

\subsection{Antimicrobial activities}

The antimicrobial activities were tested against two Gram-positive bacteria (B. cereus and $S$. chartreusis), a Gram-negative bacterium (E. coli) and a yeast (C.albicans) (Table 3 ). Whereas anhydride $\mathbf{2}$ has no effect against the microbial strains tested, compounds $\mathbf{4 , 5}$ and 7 in which the upper heterocycle is lacking, exhibited potent antimicrobial activities against the two Gram positive bacteria and inhibited strongly the sporulation of $S$. chartreusis. It is important to notice that dinitro compound $\mathbf{6}$, the most cytotoxic compound, was completely

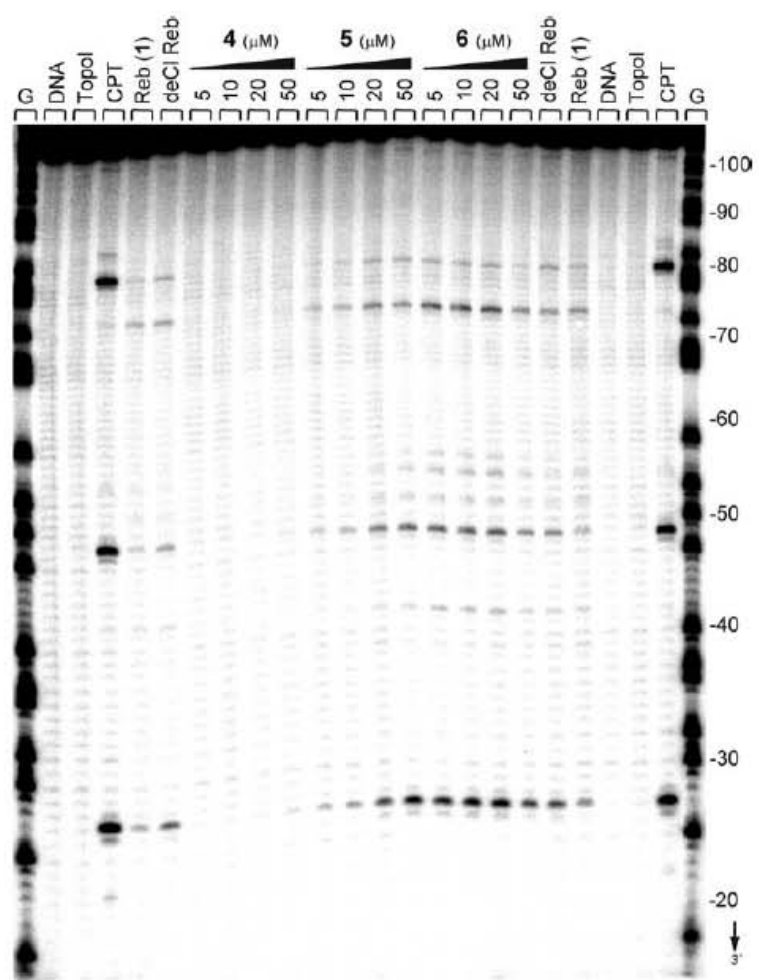

Figure 7. Cleavage of the 117-mer DNA fragment by human topoisomerase $I$ in the presence of compounds 4,5 and 6 . The $3^{\prime}$-end labeled fragment (DNA) was incubated in the absence (lane TopoI) or presence of the test drug at the indicated $\mu \mathrm{M}$ concentration. Camptothecin (CPT), rebeccamycin (Reb, 1) and dechlorinated rebeccamycin (deCl Reb) were used at $20 \mu \mathrm{M}$. Topoisomerase I cleavage reactions were analyzed on a $8 \%$ denaturing polyacrylamide gel. Numbers at the right side of the gel show the nucleotide positions, determined with reference to the guanine tracks labeled $\mathrm{G}$.

inactive. This could be due to the absence of the cellular targets of this compound in the microorganisms tested. Interestingly, the regioisomers $\mathbf{4}$ are the only compounds in this series which exhibit antimicrobial activity against the Gram negative E. coli. Surprisingly, in spite of their structures similar to that of tjipanazoles, none of the compounds of this series had antifungal activity against $C$. albicans. The chlorine atoms on the aromatic moieties of tjipanazoles could be necessary for retaining the antifungal activity. Comparison of the antimicrobial activities of compounds 4 and 7 showed that the methyl group had no influence on the activity against the Gram positive bacteria but induced growth inhibition of $E$. coli.

\section{Conclusion}

In conclusion, in the course of structure-activity relationship studies on rebeccamycin analogues, compounds structurally related to the antifungal tjipanazoles A1 and A2 have been prepared in few steps from rebeccamycin. Surprisingly, the new synthesized compounds have no antifungal activity against $C$. albicans but compounds 4,5 and 7 exhibit a strong antimicrobial activity against the two Gram positive bacteria tested, moreover compound $\mathbf{4}$ is also efficient against the Gram 
negative strain $E$. coli. The dinitro compound 6 exhibits a profile of cytotoxicity toward the nine tumor cell lines tested similar to that of rebeccamycin, which indicates that the upper heterocycle is not absolutely required for the cytotoxicity. Compound $\mathbf{6}$ induces a much stronger accumulation of L1210 cells in the G2 + M phases than rebeccamycin. It could be due to the inhibition of enzymes such as CDK1 that control the progression of the cell cycle through $\mathrm{G} 2+\mathrm{M}$ phases. However compound 6 did not inhibit CDK1. Compound 6 , and to a minor extent compound $\mathbf{5}$, were found to inhibit topoisomerase I by promoting topoisomerase I-induced DNA cleavage. The cleavage patterns were similar to those observed with the well known topoisomerase I inhibitor camptothecin and identical to those obtained with rebeccamycin and dechlorinated rebeccamycin. So, the cytotoxicity of compounds $\mathbf{5}$ and $\mathbf{6}$ seems to be linked to their capacity to inhibit topoisomerase I. The work reported here thus provides a new avenue to the design of topoisomerase I poisons based on the tjipanazole architecture.

\section{Experimental}

\subsection{Chemistry}

IR spectra were recorded on a Perkin-Elmer 881 spectrometer $\left(v\right.$ in $\left.\mathrm{cm}^{-1}\right)$. NMR spectra were performed on a Bruker $\mathrm{AC} 400\left({ }^{1} \mathrm{H}: 400 \mathrm{MHz},{ }^{13} \mathrm{C}: 100 \mathrm{MHz}\right)$ (chemical shifts $\delta$ in ppm, the following abbreviations are used: singlet (s), doublet (d), triplet (t), doubled triplet $(\mathrm{dt})$, multiplet $(\mathrm{m})$, tertiary carbons (C tert), quaternary carbons (C quat). The signals were assigned from ${ }^{1} \mathrm{H}-{ }^{1} \mathrm{H}$ $\mathrm{COSY}$ and ${ }^{13} \mathrm{C}-{ }^{1} \mathrm{H}$ correlations. Mass spectra $(\mathrm{FAB}+)$ were determined at CESAMO (Talence, France) on a high resolution Fisons Autospec-Q spectrometer. Chromatographic purifications were performed by flash silicagel Geduran SI 60 (Merck) $0.040-0.063 \mathrm{~mm}$ or Kieselgel 60 (Merck) 0.063-0.200 mm column chromatography. For purity tests, TLC were performed on fluorescent silica gel plates $\left(60 \mathrm{~F}_{254}\right.$ from Merck). Rebeccamycin was from our laboratory stock sample.

4.1.1. 12 -(4-O-methyl- $\beta$-D - glucopyranosyl) - 6,7,12,13 tetrahydro-7-oxo-indolo[2,3- $a \mid$ furo[3,4- $c \mid$ carbazole and 12 - (4- $O$-methyl- $\beta$-D -glucopyranosyl) - 6,7,12,13-tetrahydro-5-oxo-indolo[2,3-a]furo[3,4-c]carbazole (3). 11-(4$O$-methyl- $\beta$-D-glucopyranosyl)-5-methyl-6,7,12,13-tetrahydroindolo $|2,3-a|$ carbazole and 11-(4-O-methyl- $\beta$-D glucopyranosyl)-6-methyl-6,7,12,13-tetrahydroindolo[2,3$a$ a carbazole (4). To a solution of dechlorinated rebeccamycin anhydride 2 (872 $\mathrm{mg}, 1.74 \mathrm{mmol})$ in ethanol (80 $\mathrm{mL})$ was added zinc-amalgam $(7.5 \mathrm{~g})$ and $6 \mathrm{~N} \mathrm{HCl}(18$ $\mathrm{mL}$ ). The mixture was refluxed for $5 \mathrm{~h}$. After filtration and extraction with EtOAc, the organic phase was washed with saturated $\mathrm{NaHCO}_{3}$ and brine, and dried over $\mathrm{MgSO}_{4}$. The solvent was removed and the residue purified by flash chromatography (eluent, EtOAccyclohexane $7: 3)$ to give $4(298 \mathrm{mg}, 0.67 \mathrm{mmol}, 38 \%$ yield) and 3 (208 mg, $0.43 \mathrm{mmol}, 25 \%$ yield) as white solids.
3 Regioisomers ratio: 4/1 from ${ }^{1} \mathrm{H}$ at 9.12 and $9.19 \mathrm{ppm}$.

IR $(\mathrm{KBr}) v_{\mathrm{CO}} 1723 \mathrm{~cm}^{-1}, v_{\mathrm{NH}}$ OH $3200-3600 \mathrm{~cm}^{-1}$. HRMS $(\mathrm{M}+\mathrm{H})^{+}$calcd for $\mathrm{C}_{27} \mathrm{H}_{25} \mathrm{~N}_{2} \mathrm{O}_{7}, 489.1662$, found, 489.1663 .

${ }^{1} \mathrm{H}$ NMR (400 MHz, DMSO- $\left.d_{6}\right): 3.72$ and $3.73(3 \mathrm{H}, 2 \mathrm{~s})$, $3.54-4.11(\mathrm{~m}, 6 \mathrm{H}), 5.00$ and $5.09(1 \mathrm{H}, 2 \mathrm{~d}, J=5.4 \mathrm{~Hz}$, $\mathrm{OH}), 5.36$ and $5.39(1 \mathrm{H}, 2 \mathrm{~d}, J=5.4 \mathrm{~Hz}, \mathrm{OH}), 6.10$ and $6.11(2 \mathrm{H}, 2 \mathrm{~s}), 6.22$ and $6.25(1 \mathrm{H}, 2 \mathrm{br} \mathrm{s}, \mathrm{OH}), 6.34$ and $6.36\left(1 \mathrm{H}, 2 \mathrm{~d}, J=9.3 \mathrm{~Hz}, \mathrm{H}_{1^{\prime}}\right), 7.37(1 \mathrm{H}, \mathrm{t}, J=7.4 \mathrm{~Hz})$, $7.43(1 \mathrm{H}, \mathrm{t}, J=7.4 \mathrm{~Hz}), 7.58(1 \mathrm{H}, \mathrm{t}, J=7.9 \mathrm{~Hz}), 7.60$ $(1 \mathrm{H}, \mathrm{t}, J=7.4 \mathrm{~Hz}), 7.76$ and $7.79(1 \mathrm{H}, 2 \mathrm{~d}, J=7.9 \mathrm{~Hz})$, 7.99 and $8.03(1 \mathrm{H}, 2 \mathrm{~d}, J=7.9 \mathrm{~Hz}), 8.05$ and $8.10(1 \mathrm{H}$, $2 \mathrm{~d}, J=7.9 \mathrm{~Hz}), 9.12$ and $9.19(1 \mathrm{H}, 2 \mathrm{~d}, J=7.9 \mathrm{~Hz}), 11.52$ and $11.72\left(1 \mathrm{H}, 2 \mathrm{~s}, \mathrm{~N}_{\text {indole }}-\mathrm{H}\right)$.

${ }^{13} \mathrm{C}$ NMR (100 MHz, DMSO- $\left.d_{6}\right): 58.6\left(\mathrm{C}_{6^{\prime}}\right), 60.1$ $\left(\mathrm{OCH}_{3}\right), 69.7$ and $69.8\left(\mathrm{CH}_{2}\right), 73.2,73.3,76.4,76.6$, 77.1, 77.2, 77.4, 84.1 ( $\left.\mathrm{C}_{1^{\prime}}, \mathrm{C}_{2^{\prime}}, \mathrm{C}_{3^{\prime}}, \mathrm{C}_{4^{\prime}}, \mathrm{C}_{5^{\prime}}\right), 110.4,114.0$, $115.2,116.6,118.2,121.8,122.2,123.2,123.6,125.1$, $126.3,128.2,129.9,136.9,138.6,139.6,139.7,139.8$, 139.9, 140.8 (C quat arom), 111.3, 111.7, 112.1, 112.4, $119.1,119.3,119.5,119.7,120.0,120.7,121.2,121.3$, 121.6, 124.1, 124.2, $125.8(\mathrm{C}$ tert arom $), 171.9(\mathrm{C}=\mathrm{O})$.

4 Regioisomers ratio: $1.25 / 1$ from ${ }^{1} \mathrm{H}$ at 6.15 and 6.22 ppm. IR $(\mathrm{KBr}) v_{\mathrm{NH}}$ OH $3200-3600 \mathrm{~cm}^{-1}$.

HRMS (FAB +$)\left(\mathrm{M}^{+}\right)$calcd for $\mathrm{C}_{26} \mathrm{H}_{26} \mathrm{~N}_{2} \mathrm{O}_{5}$, 446.1842, found, 446.1849 .

${ }^{1} \mathrm{H}$ NMR (400 MHz, DMSO- $\left.d_{6}\right): 3.44\left(3 \mathrm{H}, \mathrm{s}, \mathrm{CH}_{3}\right)$, $3.57-4.05(6 \mathrm{H}, \mathrm{m}), 3.73\left(3 \mathrm{H}, \mathrm{s}, \mathrm{OCH}_{3}\right), 4.93$ and 4.97 $(1 \mathrm{H}, 2 \mathrm{~d}, J=5.5 \mathrm{~Hz}, \mathrm{OH}), 5.31$ and $5.33(1 \mathrm{H}, 2 \mathrm{~d}, J=5.6$ $\mathrm{Hz}, \mathrm{OH}), 6.10(1 \mathrm{H}, \mathrm{m}, \mathrm{OH}), 6.15$ and $6.22(1 \mathrm{H}, 2 \mathrm{~d}$, $\left.J=9.0 \mathrm{~Hz}, \mathrm{H}_{1^{\prime}}\right), 7.25(1 \mathrm{H}, \mathrm{t}, J=7.1 \mathrm{~Hz}), 7.30(1 \mathrm{H}, \mathrm{t}$, $J=7.1 \mathrm{~Hz}), 7.45(2 \mathrm{H}, \mathrm{m}), 7.64$ and $7.70(1 \mathrm{H}, 2 \mathrm{~d}, J=8.0$ $\mathrm{Hz}), 7.81$ and $7.88(1 \mathrm{H}, 2 \mathrm{~s}), 7.83$ and $7.90(1 \mathrm{H}, 2 \mathrm{~d}$, $J=7.9 \mathrm{~Hz}), 8.17$ and $8.21(1 \mathrm{H}, 2 \mathrm{~d}, J=7.1 \mathrm{~Hz}), 8.26$ and $8.28(1 \mathrm{H}, 2 \mathrm{~d}, J=7.1 \mathrm{~Hz}), 11.00$ and $11.13(1 \mathrm{H}, 2 \mathrm{~s}$, $\left.\mathrm{N}_{\text {indole }}-\mathrm{H}\right)$.

${ }^{13} \mathrm{C}$ NMR (100 MHz, DMSO- $\left.d_{6}\right): 21.0$ and $21.3\left(\mathrm{CH}_{3}\right)$, $58.7\left(\mathrm{C}_{6}\right), 60.0\left(\mathrm{OCH}_{3}\right), 73.2,73.3,76.7,77.0,77.4,84.1$ $\left(\mathrm{C}_{1^{\prime}}, \mathrm{C}_{2^{\prime}}, \mathrm{C}_{3^{\prime}}, \mathrm{C}_{4^{\prime}}, \mathrm{C}_{5^{\prime}}\right), 111.1,111.3,111.7,111.8,112.2$, $113.9,119.5,121.6,124.1,124.5$ (C tert arom), 120.1, $120.9,121.2,122.2,123.2,123.4,123.6,124.2,124.9$, $125.1,126.3,139.6,139.8,140.7,140.8$ (C quat arom).

4.1.3. 11-(4- $O$-methyl- $\beta$-D-glucopyranosyl)-6-formyl-5methyl - 6,7,12,13 - tetrahydroindolo $[2,3-a]$ carbazole (5). To regioisomers $4(298 \mathrm{mg}, 0.67 \mathrm{mmol})$ at $0{ }^{\circ} \mathrm{C}$ was added acetic anhydride $(699 \mathrm{mg}, 6.8 \mathrm{mmol})$ then pyridine $(1.18 \mathrm{~g}, 15 \mathrm{mmol})$. The mixture was stirred at room temperature for $20 \mathrm{~h}$, then poured into water and extracted with EtOAc. The organic phase was washed with saturated $\mathrm{NaHCO}_{3}$ and brine, and dried over $\mathrm{MgSO}_{4}$. The solvent was removed and the residue purified by flash chromatography (eluent, EtOAccyclohexane $3: 7$ ) to give a mixture of conformers of the triacetylated intermediate $(275 \mathrm{mg}, 0.48 \mathrm{mmol}, 71 \%$ yield). 
To the triacetylated intermediate $(275 \mathrm{mg}, 0.48 \mathrm{mmol})$ in dichloromethane $(5 \mathrm{~mL})$ was added $\alpha$, $\alpha$-dichloromethyl methyl ether $(0.13 \mathrm{~mL}, 1.4 \mathrm{mmol})$. The mixture was cooled to $0{ }^{\circ} \mathrm{C}$ before addition of $1 \mathrm{M} \mathrm{TiCl}{ }_{4}$ in $\mathrm{CH}_{2} \mathrm{Cl}_{2}(1.4 \mathrm{~mL}, 1.4 \mathrm{mmol})$ then stirred at room temperature for $24 \mathrm{~h}$. The mixture was poured into water and stirred at room temperature for $30 \mathrm{~min}$. After extraction with $\mathrm{CH}_{2} \mathrm{Cl}_{2}$, the organic phase was washed with brine and dried over $\mathrm{MgSO}_{4}$. After removal of the solvent, the residue was dissolved in methanol $(25 \mathrm{~mL})$ before addition of $30 \%$ aqueous $\mathrm{NH}_{4} \mathrm{OH}(10 \mathrm{~mL})$. After stirring for $24 \mathrm{~h}$ at room temperature, the mixture was evaporated to dryness. The residue was dissolved in a mixture of EtOAc-THF, acidified with $1 \mathrm{~N} \mathrm{HCl}$ and extracted with EtOAc. The organic phase was dried over $\mathrm{MgSO}_{4}$ and the solvent was removed. Chromatographic purification of the residue (eluent cyclohexane-acetone) allowed the isolation of compound 5 as a white solid $(63 \mathrm{mg}, 0.138$ mmol, $29 \%$ yield).

5: Mp $175-177^{\circ} \mathrm{C}$. IR (KBr) $v_{\mathrm{CO}} 1719 \mathrm{~cm}^{-1}, v_{\mathrm{NH}, \mathrm{OH}}$ $3200-3600 \mathrm{~cm}^{-1}$. HRMS (FAB + ) $\left(\mathrm{M}^{+}\right)$calcd for $\mathrm{C}_{27} \mathrm{H}_{26} \mathrm{~N}_{2} \mathrm{O}_{6} 474.1791$, found 474.1792 .

${ }^{1} \mathrm{H}$ NMR (400 MHz, DMSO- $\left.d_{6}\right): 3.31\left(3 \mathrm{H}, \mathrm{s}, \mathrm{CH}_{3}\right), 3.58$ $\left(1 \mathrm{H}, \mathrm{m}, \mathrm{H}_{2^{\prime}}\right), 3.70\left(3 \mathrm{H}, \mathrm{s}, \mathrm{OCH}_{3}\right), 3.72-3.84\left(2 \mathrm{H}, \mathrm{m}, \mathrm{H}_{3^{\prime}}\right.$, $\left.\mathrm{H}_{4^{\prime}}\right), 3.92\left(1 \mathrm{H}, \mathrm{m}, \mathrm{H}_{6^{\prime}}\right), 3.98-4.06\left(2 \mathrm{H}, \mathrm{m}, \mathrm{H}_{6^{\prime}}, \mathrm{H}_{5^{\prime}}\right), 4.94$ $\left(1 \mathrm{H}, \mathrm{d}, J=5.5 \mathrm{~Hz}, \mathrm{OH}_{2^{\prime}}\right), 5.31\left(1 \mathrm{H}, \mathrm{d}, J=5.8 \mathrm{~Hz}, \mathrm{OH}_{3^{\prime}}\right)$, $6.15\left(1 \mathrm{H}, \mathrm{t}, J=4.0 \mathrm{~Hz}, \mathrm{OH}_{6^{\prime}}\right), 6.28(1 \mathrm{H}, \mathrm{d}, J=9.0 \mathrm{~Hz}$, $\left.\mathrm{H}_{1^{\prime}}\right), 7.27(1 \mathrm{H}, \mathrm{t}, J=7.4 \mathrm{~Hz}, \mathrm{Hc}), 7.38\left(1 \mathrm{H}, \mathrm{dt}, J_{1}=8.0\right.$ $\left.\mathrm{Hz}, J_{2}=0.7 \mathrm{~Hz}, \mathrm{Hc}^{\prime}\right), 7.52\left(1 \mathrm{H}, \mathrm{dt}, J_{1}=8.1 \mathrm{~Hz}, J_{2}=0.8\right.$ $\left.\mathrm{Hz}, \mathrm{H}_{\mathrm{B}}\right), 7.56\left(1 \mathrm{H}, \mathrm{t}, J=7.7 \mathrm{~Hz}, \mathrm{H}_{\mathrm{B}^{\prime}}\right), 7.77(1 \mathrm{H}, \mathrm{d}$, $\left.J=8.1 \mathrm{~Hz}, \mathrm{H}_{\mathrm{A}}\right), 7.95\left(1 \mathrm{H}, \mathrm{d}, J=8.5 \mathrm{~Hz}, \mathrm{H}_{\mathrm{A}}\right), 8.42(1 \mathrm{H}$, $\left.\mathrm{d}, J=8.0, \mathrm{H}_{\mathrm{D}^{\prime}}\right), 8.62\left(1 \mathrm{H}, \mathrm{d}, J=8.0 \mathrm{~Hz}, \mathrm{H}_{\mathrm{D}}\right), 11.18(1 \mathrm{H}$, $\mathrm{s}, \mathrm{CHO}), 11.59(1 \mathrm{H}, \mathrm{s}, \mathrm{NH})$.

${ }^{13} \mathrm{C}$ NMR (100 MHz, DMSO- $\left.d_{6}\right): 16.5\left(\mathrm{CH}_{3}\right), 58.6\left(\mathrm{C}_{6^{\prime}}\right)$, $60.1\left(\mathrm{OCH}_{3}\right), 73.0,76.5,77.0,77.3,84.0\left(\mathrm{C}_{1^{\prime}}, \mathrm{C}_{2^{\prime}}, \mathrm{C}_{3^{\prime}}\right.$, $\left.\mathrm{C}_{4^{\prime}}, \mathrm{C}_{5^{\prime}}\right), 111.6,112.2,119.7,120.3,122.6,124.4,125.1$, 125.4 (C tert arom), 120.1, 121.6, 122.1, 122.7, 123.8, $124.1,129.3,132.2,140.0,141.7$ (C quat arom), 192.5 (CHO).

4.1.4. 11-(4- $O$-methyl- $\beta$-D-glucopyranosyl)-3,6-dinitro-5methyl-6,7,12,13-tetrahydroindolo $|2,3-a|$ carbazole (6). To THF $(6 \mathrm{~mL})$ at $0^{\circ} \mathrm{C}$ was slowly added fuming $\mathrm{HNO}_{3}(0.84 \mathrm{~mL}) .3 \mathrm{~mL}$ of the above solution was added to the triacetylated intermediate $(173 \mathrm{mg}, 0.30 \mathrm{mmol})$, the mixture was allowed to reach room temperature and was stirred for $6 \mathrm{~h}$ at room temperature before addition of $3 \mathrm{~mL}$ of the solution of $\mathrm{HNO}_{3}$ in THF. The mixture was stirred for $12 \mathrm{~h}$. After evaporation of the solvent, the residue was purified by flash chromatography (eluent, EtOAc-cyclohexane, 40:60) to give a diacetylated intermediate $(83 \mathrm{mg})$ and a monoacetylated intermediate $(22 \mathrm{mg})$.

To the diacetylated intermediate $(83 \mathrm{mg})$ in $\mathrm{MeOH}$ (12 $\mathrm{mL}$ ) was added $30 \%$ aqueous $\mathrm{NH}_{4} \mathrm{OH}(5 \mathrm{~mL})$. After stirring for $24 \mathrm{~h}$ at room temperature, the mixture was evaporated to dryness. The residue was dissolved in a mixture of EtOAc-THF, acidified with $1 \mathrm{~N} \mathrm{HCl}$ and extracted with EtOAc. The organic phase was dried over $\mathrm{MgSO}_{4}$ and the solvent was removed. The residue was purified by PLC (eluent MeOH-EtOAc, 98:2) to give 6 (20 mg, $0.037 \mathrm{mmol}, 12 \%$ yield) as a yellow solid.

6: $\mathrm{Mp}>300^{\circ} \mathrm{C}$. IR $(\mathrm{KBr}) v_{\mathrm{CO}} 1730,1740 \mathrm{~cm}^{-1}, v_{\mathrm{NH}, \mathrm{OH}}$ $3100-3600 \mathrm{~cm}^{-1}$.

${ }^{1} \mathrm{H}$ NMR (400 MHz, DMSO- $\left.d_{6}\right): 3.44\left(3 \mathrm{H}, \mathrm{s}, \mathrm{CH}_{3}\right), 3.70$ $\left(3 \mathrm{H}, \mathrm{s}, \mathrm{OCH}_{3}\right), 3.45-4.30(6 \mathrm{H}, \mathrm{m}), 5.00(1 \mathrm{H}, \mathrm{d}, J=5.4$ $\mathrm{Hz}, \mathrm{OH}), 5.36(1 \mathrm{H}, \mathrm{d}, J=4.4 \mathrm{~Hz}, \mathrm{OH}), 6.35(1 \mathrm{H}, \mathrm{d}$, $\left.J=9.0 \mathrm{~Hz}, \mathrm{H}_{1^{\prime}}\right), 6.44(1 \mathrm{H}$, br s, OH$), 7.37(1 \mathrm{H}, \mathrm{t}, J=8.2$ $\mathrm{Hz}), 7.58(1 \mathrm{H}, \mathrm{t}, J=8.0 \mathrm{~Hz}), 7.86(1 \mathrm{H}, \mathrm{d}, J=9.0 \mathrm{~Hz})$, $7.98(1 \mathrm{H}, \mathrm{d}, J=8.5 \mathrm{~Hz}), 8.46(1 \mathrm{H}, \mathrm{d}, J=9.0 \mathrm{~Hz}), 8.90$ $(1 \mathrm{H}, \mathrm{s}), 9.09(1 \mathrm{H}, \mathrm{d}, J=7.9 \mathrm{~Hz}), 12.12(1 \mathrm{H}, \mathrm{s}, \mathrm{NH})$.

${ }^{13} \mathrm{C}$ NMR (400 MHz, DMSO- $\left.d_{6}\right): 58.2\left(\mathrm{C}_{6^{\prime}}\right), \quad 59.9$ $\left(\mathrm{OCH}_{3}\right), 18.6\left(\mathrm{CH}_{3}\right), 71.0,73.3,75.3 ; 77.0,81.6\left(\mathrm{C}_{1^{\prime}}\right.$, $\left.\mathrm{C}_{2^{\prime}}, \mathrm{C}_{3^{\prime}}, \mathrm{C}_{4^{\prime}}, \mathrm{C}_{5^{\prime}}\right), 111.4,112.7,117.9,121.0,121.3$, $124.5,126.7$ (C tert arom), 111.9, 114.1, 119.9, 121.6 (2C), 125.3, 131.0, 139.1, 140.4, 141.4, 143.0 (C quat arom).

\subsection{Growth inhibition assays}

Tumor cells were provided by American Type Culture Collection (Frederik, MD, USA). They were cultivated in RPMI 1640 medium (Life Science technologies, Cergy-Pontoise, France) supplemented with $10 \%$ fetal calf serum, $2 \mathrm{mM}$ L-glutamine, 100 units $/ \mathrm{mL}$ penicillin, $100 \mu \mathrm{g} / \mathrm{mL}$ streptomycin, and $10 \mathrm{mM}$ HEPES buffer $(\mathrm{pH}=7.4)$. Cytotoxicity was measured by the microculture tetrazolium assay as described. ${ }^{25}$ Cells were continuously exposed to graded concentrations of the compounds for four doubling times, then $15 \mu \mathrm{L}$ of 5 $\mathrm{mg} / \mathrm{mL}$ 3-(4,5-dimethylthiazol-2-yl)-2,5-diphenyltetrazolium bromide were added to each well and the plates were incubated for $4 \mathrm{~h}$ at $37^{\circ} \mathrm{C}$. The medium was then aspirated and the formazan solubilized by $100 \mu \mathrm{L}$ of DMSO. The results are expressed as $\mathrm{IC}_{50}$, concentration which reduced by $50 \%$ the optical density of treated cells with respect to untreated controls.

\subsection{Cell cycle analysis}

For the cell cycle analysis, L1210 cells $\left(2.5 \times 10^{5}\right.$ cells/ $\mathrm{mL}$ ) were incubated for $21 \mathrm{~h}$ with various concentrations of the compounds, then fixed by $70 \%$ ethanol $(\mathrm{v} /$ v), washed and incubated in PBS containing $100 \mu \mathrm{g} / \mathrm{mL}$ RNAse and $25 \mu \mathrm{g} / \mathrm{mL}$ propidium iodide for $30 \mathrm{~min}$ at $20^{\circ} \mathrm{C}$. For each sample, $10^{4}$ cells were analyzed on a $\mathrm{XL} / \mathrm{MCL}$ flow cytometer (Beckman Coulter). The fluorescence of propidium iodide was collected through a $615 \mathrm{~nm}$ long-pass filter.

\subsection{Topoisomerase I inhibition}

Recombinant topoisomerase I protein was produced and purified from baculovirus infected Sf 9 cells. ${ }^{26}$ Some experiments were also performed with a commercially available enzyme (TopoGen Inc.). Supercoiled pLAZ3 DNA $(0.4 \mu \mathrm{g})$ was incubated with 4 units human topoisomerase I at $37^{\circ} \mathrm{C}$ for $1 \mathrm{~h}$ in relaxation buffer $(50 \mathrm{mM}$ Tris $\mathrm{pH} 7.8,50 \mathrm{mM} \mathrm{KCl}, 10 \mathrm{mM} \mathrm{MgCl}_{2}, 1 \mathrm{mM}$ 
dithiothreitol, $1 \mathrm{mM}$ EDTA) in the presence of varying concentrations of the drug under study. Reactions were terminated by adding SDS to $0.25 \%$ and proteinase $\mathrm{K}$ to $250 \mu \mathrm{g} / \mathrm{mL}$. DNA samples were then added to the electrophoresis dye mixture $(3 \mu \mathrm{L})$ and electrophoresed at room temperature for $2 \mathrm{~h}$ at $120 \mathrm{~V}$ in $1 \%$ agarose gels containing ethidium bromide $(1 \mu \mathrm{g} / \mathrm{mL})$. After electrophoresis, gels were washed and photographed under UV light. ${ }^{17}$

\subsection{Sequencing of topoisomerase I-mediated DNA cleavage sites}

The 117 base pairs DNA fragment was prepared by $3^{\prime}-$ $\left[{ }^{32} \mathrm{P}\right]$-end labeling of the EcoRI-PvuII double digest of the plasmid pBS using $\alpha-\left[{ }^{32} \mathrm{P}\right]-\mathrm{dATP}(3000 \mathrm{Ci} / \mathrm{mMol})$ and $\mathrm{AMV}$ reverse transcriptase. Each reaction mixture contained $2 \mu \mathrm{L}$ of $3^{\prime}$-end $\left.{ }^{32} \mathrm{P}\right]$ labeled DNA $(\sim 1 \mu \mathrm{M}), 5$ $\mu \mathrm{L}$ of water, $2 \mu \mathrm{L}$ of $10 \times$ topoisomerase I buffer, $10 \mu \mathrm{L}$ of drug solution at the desired concentration (10-100 $\mu \mathrm{M})$. After $10 \mathrm{~min}$ incubation to ensure equilibration, the reaction was initiated by addition of $2 \mu \mathrm{L}$ ( 20 units) topoisomerase I. Samples were incubated for $45 \mathrm{~min}$ at $37^{\circ} \mathrm{C}$ prior to adding SDS to $0.25 \%$ and proteinase $\mathrm{K}$ to $250 \mu \mathrm{g} / \mathrm{mL}$ to dissociate the drug-DNA-topoisomerase I cleavable complexes. The DNA was precipitated with ethanol and then resuspended in $5 \mu \mathrm{L}$ of formamide-TBE loading buffer, denatured at $90{ }^{\circ} \mathrm{C}$ for 4 min then chilled in ice for $4 \mathrm{~min}$ prior to loading on to the sequencing gel. DNA cleavage products were resolved by polyacrylamide gel electrophoresis under denaturing conditions.

\subsection{Antibiogram tests}

Five strains were tested, two Gram positive bacteria ( $B$. cereus ATCC 14579, $S$. chartreusis NRRL 11407), a Gram negative bacterium (E. coli ATCC 11303) and a yeast (Candida albicans 444 from Pasteur Institute). The antimicrobial activities were determined by the conventional paper disk (Durieux $\mathrm{N}^{\circ} 268$; $6 \mathrm{~mm}$ in diameter) diffusion method using the following nutrient media: Mueller-Hinton (Difco) for B. cereus and E. coli, Sabouraud agar (Difco) for C. albicans and Emerson agar $(0.4 \%$ beef extract, $0.4 \%$ peptone, $1 \%$ dextrose, $0.25 \% \mathrm{NaCl}, 2 \%$ agar, $\mathrm{pH} 7.0$ ) for the Streptomyces strain. Products were dissolved in DMSO and a paper disk containing each of the products $(300 \mu \mathrm{g})$ was placed on Petri dishes. Growth inhibition was examined after $24 \mathrm{~h}$ incubation at $27^{\circ} \mathrm{C}$.

\section{Acknowledgements}

C.B. thanks William Laine for expert assistance with the topoisomerase I experiments and the Ligue Nationale Contre le Cancer (Equipe labellisée LA LIGUE) for financial support.

\section{References and notes}

1. Bonjouklian, R.; Smitka, T. A.; Doolin, L. E.; Molloy, R. M.; Debono, M.; Shaffer, S. A.; Moore, R. E.; Stewart, J. B.; Patterson, G. M. L. Tetrahedron 1991, 47, 7739.

2. Tamaoki, T.; Nomoto, H.; Takahashi, I.; Kato, Y.; Morimoto, M.; Tomita, F. Biochem. Biophys. Res. Commun. 1986, 135, 397.

3. Kase, H.; Iwahashi, K.; Matsuda, Y. J. Antibiot. 1986, 39, 1059.

4. Bush, J. A.; Long, B. H.; Catino, J. J.; Bradner, W. T.; Tomita, K. J. Antibiot. 1987, 40, 668.

5. Gilbert, E. J.; Van Vranken, D. L. J. Am. Chem. Soc. $1996,118,5500$.

6. Gilbert, E. J.; Ziller, J. W.; Van Vranken, D. L. Tetrahedron 1997, 53, 16553.

7. Shankar, B. B.; Mc Combie, S. W. Tetrahedron Lett. 1994, 35, 3005.

8. Somei, M.; Yamada, F.; Kato, J.; Suzuki, Y.; Ueda, Y. Heterocycles 2002, 56, 81 .

9. Stoltz, B. M.; Wood, J. L. Tetrahedron Lett. 1996, 37, 3929.

10. Shankar, B. B.; Mc Combie, S. W.; Kirkup, M. P.; Viet, A. Q.; Puar, M. S.; Ganguly, A. K. Tetrahedron Lett. $1993,34,5685$.

11. Stoltz, B. M.; Wood, J. L. Tetrahedron Lett. 1995, 36, 8543.

12. Wood, J. L.; Stoltz, B. M.; Onwueme, K.; Goodman, S. N. Tetrahedron Lett. 1996, 37, 7335.

13. Wood, J. L.; Stoltz, B. M.; Dietrich, H. J.; Pflum, D. A.; Petsch, D. T. J. Am. Chem. Soc. 1997, 119, 9641

14. Fabre, S.; Prudhomme, M.; Sancelme, M.; Rapp, M. Bioorg. Med. Chem. 1994, 2, 73.

15. Moreau, P.; Anizon, F.; Sancelme, M.; Prudhomme, M.; Bailly, C.; Carrasco, C.; Ollier, M.; Sevère, D.; Riou, J.-F.; Fabbro, D.; Meyer, T.; Aubertin, A.-M. J. Med. Chem. 1998, 41, 1631.

16. Anizon, F.; Belin, L.; Moreau, P.; Sancelme, M.; Voldoire, A.; Prudhomme, M.; Ollier, M.; Sevère, D.; Riou, J. F.; Bailly, C.; Fabbro, D.; Meyer, T. J. Med. Chem. 1997, 40, 3456.

17. Anizon, F.; Moreau, M.; Sancelme, M.; Laine, W.; Bailly, C.; Prudhomme, M. Bioorg. Med. Chem. 2003, 11, 3709.

18. Rodrigues Pereira, E.; Belin, L.; Sancelme, M.; Prudhomme, M.; Ollier, M.; Rapp, M.; Sevère, D.; Riou, J.-F.; Fabbro, D.; Meyer, T. J. Med. Chem. 1996, 39, 4471.

19. Moreau, P.; Anizon, F.; Sancelme, M.; Prudhomme, M.; Sevère, D.; Riou, J.-F.; Goossens, J-F.; Hénichart, J.-P.; Bailly, C.; Labourier, E.; Tazi, J.; Fabbro, D.; Meyer, T.; Aubertin, A.-M. J. Med. Chem. 1999, 42, 1816.

20. Yamada, R.; Seto, M.; Sasaki, Y.; Sunazuka, T.; Harigaya, Y.; Iwai, Y.; Omura, S. J. Antibiot. 1996, 49, 1070.

21. Magnus, P. D.; Sear, N. L. Tetrahedron 1984, 40, 2795.

22. Marminon, C.; Anizon, F.; Moreau, P.; Léonce, S.; Pierré, A.; Pfeiffer, B.; Renard, P.; Prudhomme, M. $J$. Med. Chem. 2002, 45, 1330.

23. Moreau, P.; Anizon, F.; Sancelme, M.; Prudhomme, M.; Bailly, C.; Sevère, D.; Riou, J.-F.; Fabbro, D.; Meyer, T.; Aubertin, A.-M. J. Med. Chem. 1999, 42, 584.

24. Gilbert, E. J.; Chisholm, J. D.; Van Vranken, D. L. $J$. Org. Chem. 1999, 64, 5670.

25. Léonce, S.; Pérez, V.; Casabianca-Pignède, M. R.; Anstett, M.; Bisagni, E.; Atassi, G. Invest. New Drugs 1996, 14, 169.

26. Rossi, F.; Labourier, E.; Forné, T.; Divita, G.; Derancourt, J.; Riou, J. F.; Antoine, E.; Cathala, G.; Brunel, C.; Tazi, J. Nature 1996, 381, 80 . 